\title{
A Flat Organization Model for Agile Workforce with Reference to Holacracy
}

\author{
P. Uma Rani, A. Rachel Cynthia, S. Priyankaa, K. Murugan Kandaswamy
}

\begin{abstract}
Holacracy is a new method of arranging and managing concern which changes the conservative management chain of command. Authority is evenly allocated to all the employees irrespective of their designation; all human beings are given free hand to operate as per their vision and must match with the company's vision. We are in an aggressive globalised era and the contemporary firms look for the competent model which would help them to form a business in an agile manner and avoid redundant hierarchical levels to decrease costs. Holacracy is a new method that helps to enhance the efficiency, so that they can run the firm more successfully. Over the past few years, many firms have taken a sledgehammer to the traditional corporate hierarchy. Instead of entrusting the entire work to superior's the workers can coordinate with their group and prove their individuality. The researchers are concerned with structuring a new model that has got and its impact on organizational employee's performance which turns organization to gain cost effective process, efficient time management, and greater transparency for successful conduction of business in the competitive world.
\end{abstract}

Keywords-: Holacracy, contemporary, traditional corporate hierarchy, competitive world

\section{INTRODUCTION}

Due to globalization speedy changes are required to over come the competition. It is very difficult to forecast the atmosphere. Hence in this competitive world, if the business has to survive, they have to accommodate with a new business model and speed up their operations. Higher authorities can sit with all employees and frame policies based on the feasibility. The firm must be confident in executing the planned proposals. The mantra of quickness has to be imbibed among the employees to process their operations effectively and efficiently in such a way they are able to retain their customers..

\section{A Robust System ForDistributingAuthority}

Holacracy offers a new "communal technology" for governing and working an group - one that reliably distributes power, stiffness and self-organization into employee basis. Here the rules and processes through which

the structure itself goes in its business. "The communal technology basis modern companies has become the first

Revised Version Manuscript Received on August 19, 2019.

Dr.P.Uma Rani, Prof \&Head- DOMS, Saveetha Engineering College, Chennai, Tamilnadu, India(Email: : umarani@saveetha.ac.in)

Ms.A.Rachel Cynthia, I MBA Student, Saveetha Engineering College, Chennai, Tamil Nadu, India.(Email: : rachelcynthia01@gmail.com)

Ms.S.Priyankaa, , I MBA Student, Saveetha Engineering College, Chennai, Tamil Nadu, India.(Email: : spdlovesjesus@gmail.com)

Mr.K.MuruganKandaswamy, Asst Prof -DOMS, Saveetha Engineering College, Chennai, Tamil Nadu, India.(Email: : murugan@saveetha.ac.in) frontier to their steps forward and flexibility" Holacracy One co-founder Brian Robertson says "It enables just-in-time awareness to tensions and opportunity at every level of theorganization".

The outcome is an organization that is repeatedly growing through arrangement and processes on peer-to-peer governance. Many business leaders have suspicions about shifting to a more dispersed authority constitution, fearing that they would be fading in their fiduciary duty by allow their organizations to descend downward into leaderless chaos. Many find the plan of self-organization engaging, but self-organization doesn't occur by itself. It requires neat, hard-working, advanced chosen who know that challenging control is not the best method for triumph. Obviously, leaders can't pay for discard structure in total, and anyone who has tried management an organization by agreement knows that it can be manageable at best.

In Holacracy, top-down level is replaced with a strong and quick process which keeps each one fused as they finds that complicatedness in their business. Holacracy is often misjudged as being "flat" or "radical," it is in reality an vastly planned way to allot power and facilitate the firm, which makes easier to safeguard and correct the mistakes. Just as companies like Uber and AirBnB are efficient because they're built on sophisticated industrial platforms that allows the company to design itself. It distinguishes itself from numerous new-paradigm business practices that merely "fasten on" pioneering ideas while departure the primary operating system hurt.

\section{OBJECTIVES}

To identify new business model that directs the role of employees

To analyze the impact of new business model

The below model deals with a horizontal business organization structure which defines various sub circles within the general company circle. It consists of board circle members, Superiors and Employee level. The sub circles are arranged in the hierarchical order. Each sub circles consist of lead link role player, rep link role player and the circle members. The lead link role player will assign each roles to the circle members according to their skills. Within the subgroup, there will be two are more groups according to the different company policy framework. The rep link role player 
is selected by each group circle members within each subgroup. The circle members will make each decision according to the expectation of the organization goal and also the decision will be with a reference under the governance framework based on the Holacracy concept. Each circle members will present their own ideas in front of lead link role players. In this presentation, the circle members can raise their voice if the presenter's decision is not generally applicable to the circle members. Every after two months a governance meeting will be held, here the CEO and each group lead link role players will participate and they will discuss the status of company and about any updating to be given to the circle members.

\section{Holacracy Business model}

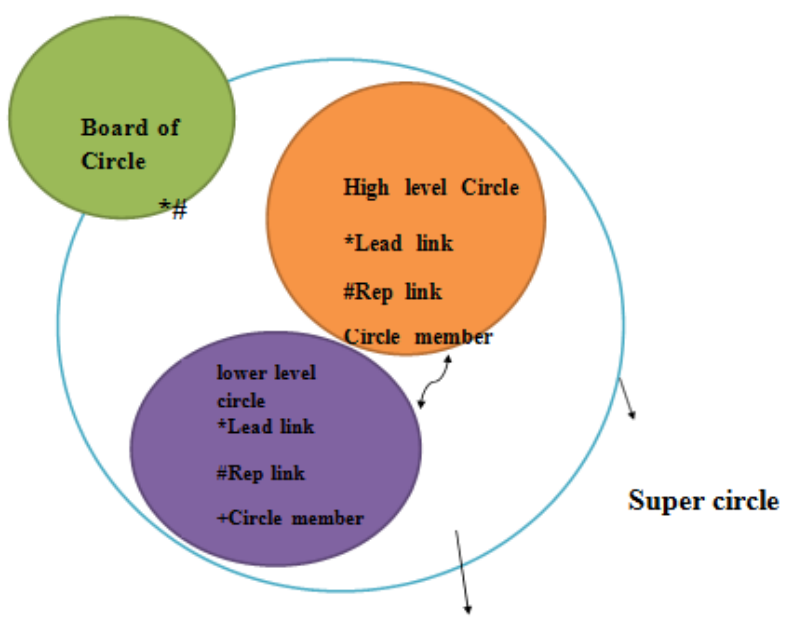

GCC (General Company Circle)

\section{FIELD REVIEW}

The researchers visited five different manufacturing companies in an around Sriperumpathur to carry out research on horizontal organization model with reference to Holacracy with the objective of analyzing the possibility of implementing the proposed model and its impact on organization performance. The researcher had interview with those companies' higher level officials to know the feasibility of the model implementation, where the selected officials responded the structured questionnaire regarding the delegation of authority and how effectively the employees perform in the absence of their superiors and how for the decentralization of power motivates employees to perform better in the organization also their swiftness in their performance to complete task allotted to every employees analyzed. This model will not be much easier to implement in large organization where it is possible to an extent in micro and small level companies like ZAPPOS (an online retailer company) in USA who adapted this concept and they experienced the huge outcome over it. The benefits of this flat model will help those organizations to reduce expenditure and gain advantage over cost which turns company to earn profit in short run. In this approach employee retention is possible and eliminates conflict between workers and their superiors, which helps to avoid work stress that leads to increase their performance in an organisation. Finally, it will lead to company sustainability in this future competitiveenvironment.

\section{PROCESS}

Holacracy structure is very transparent and the employees are aware of their responsibility and work for the benefit of the organisation. Work tension is reduced as this model avoids conflict among all levels of employees. The sense of belongingness is created among the employees that boost up their morale to work for the good of the company.

\section{MEETINGS}

Meetings are arranged in frequent intervals for all levels of employees to discuss their problems. Workers must be concerned regarding the organisation vision and mission and work towards it. When they coordinate and work with one another the chances of duplication of work can be avoided. The importance of agility in the current scenario will be stressed in those meetings, so that the employees work with involvement to complete the task in time. Under Holacracy model equal importance is given to all levels of employees which help the workers to open out their issues and sort them immediately.

\section{IMPACT OF NEW BUSINSS MODEL\& RESULTS}

Holacracy model helps for the agile movement. Holacracy does not entertain over planning, after fixing up the plan managers are very flexible enough to examine the roles and try to reschedule the plan as per the wishes of employees. In this model an employee is offered numerous roles to play and opportunity given to them to mingle with all teams in the organisation. The potentiality of each worker is discussed in the meeting and work is allotted accordingly as tailor made for them. Ideas are generated and freedom is given to all while executing their job according to their interest. Authority is given to all level of workers and they can act as leaders. In Holacracy method the organisation chart is restructured frequently. A firm is given full freedom to restructure the organsiation chart that suits them for the sustainability of the business. No rigid rules accepted under this method and the power moves from one person to another.

\section{CONCLUSION}

When Holacracy model is developed in the business, all workers will coordinate with each other and adapt to the environment. It helps the organisation to work with agility and help to increase the capacity of the worker to perform better. As this structure is new, it will take some time to shift to this new method. Organisations which have adopted this model are functioning more effectively and successfully. It gives opportunity for the workers to share their innovative ideas in the meeting, which can be carried forward; for the good of the organisation. This model reduces stress and gives them independence to work for the benefit of the organisation. Leadership is distributed and freedom is given to take up alternative work which avoids monotony in their job. Under this method control is implemented while doing the work but they are not interrupted when performing their job. There are people who work with passion and not concerned about high pay, for them this method is more suitable. Ultimately this model helps to

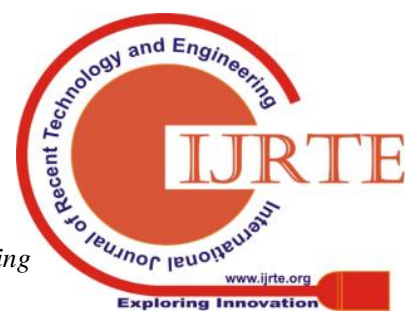


retain the good employees. Right people are placed under right job based on their skills and readiness to do the job. HR has to be more agile while recruiting so that employees work with interest and not only help them to grow but also assist the organisation also to grow.

\section{REFERENCE}

1. Aaron Dignan (2013) "The Last Re-Org You'll Ever Do" https://medium.com/the-ready/the-last-re-org-youll-ever-dof19160f61500\#.9c80q5kzh (15.05.2016.)

2. Berens, Linda, V. (2001) Understanding Yourself and Others: An Introduction to Interaction Styles. Huntington Beach, TelosPublications.

3. Cook-Greuter, Susanne (2004). Making the Case for a Developmental Perspective. Industrial and Commercial Training, Vol. 36 (7), 275 -281.

4. Holacracy.org, http://www.holacracy.org/backstory(15.05.2016.)

5. Holacracy.org,

https://glassfrog.holacracy.org/organizations/5(15.05.2016.)

6. Koestler, Arthur (1990). The Ghost in the Machine. London,Penguin. 